\title{
Design Characteristics in International News Coverage: A Comparison between the U.S and Brazil
}

\section{Danny Paskin*}

California State University, Long Beach, California, USA

\begin{abstract}
This study fills a gap in the analysis of international news coverage by comparing the design elements of international news stories in both the American and Brazilian media, identifying any common or discerning trends Best selling newspapers in both countries were examined, and a content analysis performed to compare their layout, using a number of different variables. Results show that American publications seemed to give a higher salience to international stories compared to Brazilian publications when it comes to their design.
\end{abstract}

Keywords: Brazil; United States; International; Design; Photography; Color; Placement; Online; PDF, Newspaper; Magazine; Size; Inches

\section{Introduction}

It was Walter Lippmann, famous columnist and writer, who in 1922 first addressed the question of how issues come into being and become salient in the mind of the media, the public, and the government, when he discussed the effects of propaganda in France. Since then scholars from different disciplines have dedicated hundreds of studies to understanding how, when and why some issues become more salient than others.

Among the many facets of this question of hierarchy of news in publications, the actual design of newspapers plays a part. On the day following the September 11 attacks, for example, newspapers worldwide devoted most of their front pages to the attack. American newspapers were providing higher-than-normal coverage of international issues during the days after the attack. Not only was the focus of front pages on September 12, 2011 similar - as expected - but the design of those pages was also similar - very large headlines, one-story front pages, very large photos (many times, the very same photos of the first, the second or both airplanes crashing into the towers).

While in the U.S., September 11 was domestic news, around the world it was international. In an example of globalization and technically advanced media coverage, foreign newspapers were covering the World Trade Center and Pentagon attacks non-stop. And yet, the design of the topic around the world was very similar.

A decade has passed since September 11, 2001, and much has happened since then. Although no more direct terrorist attacks have occurred inside the United States, the country has been involved in wars abroad. Even so, no scholarly study has examined the actual design of international issues. This study intends to fill this gap, by comparing the design of international news stories in both the American and Brazilian media, identifying any common or discerning trends.

\section{The design factor}

This study is vastly based on the Poynter's Eyes on the News Study [1], which analyzed how readers looked at the content of newspapers by using eye-tracking technology that defined what the eyes of readers would focus on in the page. The authors looked mostly to the importance of pictures, placement and colors in newspaper design. It can also be seen a follow-up to a previous study that analyzed the salience of international news stories in newspapers across countries [2] That study, however, looked only at quantitative factors to determine salience - number of stories printed, column-inches (size) of stories. It followed what most media agenda setting research have always done, measuring the presence of stories by the number of characters or words, while not taking into consideration other elements such as font size, which can severely skew the results: it is one thing to have 500 words in 12-point font, and another to have them in 10.5-point font - the former occupying 14.3 percent more space than the latter. Such difference does appear in print, and has been largely ignored until now. The use of headlines has also been apparently ignored. Larger headlines have a different effect than smaller headlines when calling attention to stories; they also take more space, which might be ignored as well if one is simply counting the number of words or characters, and not how those are designed. Moreover, the use of color influences how people will read the story. Finally, the location of the story within the page can also be seen as an important design factor.

This new study, then, analyzed what it referred to as the "design factor" - specific graphic design characteristics of international news that included headline font size, use and size of art, among other factors. Although studies of news design characteristics have been previously conducted, there is a clear gap in the literature when it comes to defining the relevant specific design characteristics of international stories published on the front pages, which this study does while also comparing the design of such stories in Brazil and the U.S.

Few studies $[3,4]$ have related design characteristics to news hierarchy, and virtually none have done so while focusing specifically on international news coverage. This study, then, gathered data to show the current trends of international news design, with the similarities and differences across countries among the publications sampled,

*Corresponding author: Danny Paskin, California State University, Long Beach, California, USA, Tel: 562-985-2602; Fax: 562-985-5300; E-mail: dpaskin@csulb.edu

Received December 12, 2011; Accepted January 10, 2012; Published January 12,2012

Citation: Paskin D (2012) Design Characteristics in International News Coverage: A Comparison between the U.S and Brazil. J Mass Communicat Journalism 2:107. doi:10.4172/2165-7912.1000107

Copyright: (c) 2012 Paskin D. This is an open-access article distributed under the terms of the Creative Commons Attribution License, which permits unrestricted use, distribution, and reproduction in any medium, provided the original author and source are credited. 
laying the groundwork for future similar studies. Newspaper readers choose stories to read from newspapers based on cues left by editors, writers or designers, including location, size of headline and length [3]. Visual elements can also be listed as one of the key dimensions of content analysis [5].

News design theory shows us that, when reading a newspaper, stories will have a relative inherent importance based on their design characteristics. Such design characteristics go beyond just the number of news items or the amount of space news occupies, focusing also on aspects of news design that would characterize a story as more or less important. That includes, for example, the number of lines in the headline and deck of the story; the size of type used in the headline; and the color of the headline. Such theories also tell us that the order in which people will read stories on the paper depends very much on the design of the story. Nonetheless, there are three different approaches when it comes to defining where someone's eyes will fall on a news page first: on the top-right side of the paper; anywhere on the top third of the news page (both theories, then, making it important to analyze the position of news in the page). A more complex third option involves whether stories have art; among those stories with no art, the size and color of the headline and deck (typographical elements) become crucial.

\section{Research question}

In the end, one research question was developed for this study: How does the design of international news stories published on the front page of daily newspapers in Brazil and the U.S. differ from each other?

\section{Methodology}

\section{Selection of the sample countries}

The two specific countries selected for this study - Brazil and the United States - were chosen to represent important political and economic regions: the U.S., known as the current hegemony in the world system, and Brazil, a growing representative of Latin America, who is not only a main actor in the region's political and economical systems but also a main player in the efforts for a Free Trade Area of the Americas (FTAA) in the near future.

Moreover, Brazil and the U.S. are two of the largest democracies in the world, population-wise. During its presidential election in 2000, the United States ranked second worldwide in size of voting age population and number one in number of votes [6]; Brazil, meanwhile, ranked third in voting age population in 1998 [6], and second in total number of votes during its presidential election in 2002 [7], making them two of the most important democratic countries in world politics.

Both countries also highly value freedom of information and expression. The U.S. has a long history of defending the First Amendment. Brazil, on the other hand, went through a dictatorship period from the mid-60s until the mid-80s, one that highly censored its newspapers. Since the end of the dictatorship period, however, Brazilian governments have upheld newspapers in the highest of standards, as truly a watchdog for the population.

On the other hand, the fact that Brazil and the United States present differences both economically and socially (including cultural differences) made this an even more interesting comparison, analyzing whether - despite any differences - the design of international news stories was still similar in both countries despite any outside factors.

Finally, the two countries were also selected based on feasibility. Since stories had to be compared, author needed to be able to understand/read the stories published in both countries. Since the author of this study is a native Brazilian, analysis of newspapers in both Portuguese and English was feasible.

\section{Rationale for content analysis of print media}

To acquire the necessary information for each country, a content analysis of five of the major daily papers in each country will be conducted in the same time frame for each sample, as to validate the comparison of the results. When it comes to newspaper coverage content analysis is considered the best method for researching the print media since it allows for a statistical analysis of the "textual units" (p. 104) of a certain document [8]. Furthermore, the print media, newspapers in particular, are a form of public and accessible record that are published regularly [9].

Content analysis has been used to determine media coverage of issues and compare those to the public's focus of attention since the very early stages of the study of media agenda setting. In the seminal McCombs and Shaw study of agenda setting [10], seven of the study's nine media channels analyzed were newsmagazines and newspapers, including, for example, The Los Angeles Times. And up to this day, even in the era of cable television and the internet, newspaper is still seen as having the most reporters leading to the strongest content [4].

Furthermore, most of the research on international news coverage has been done by using content analysis [11]. And, because of the time and work demands of this method, the comparison has usually been restricted to two countries [12-14] or to a specific region $[15,16]$.

No archival material could be used for this study due to the lack of available archives of Brazilian newspapers in local libraries or online, and even less availability of images of Brazilian newspaper front pages. The analysis will be conducted with a hope that no unique events occurred during the time frame of this study that would highly skew the coverage. The random sampling method is used in this case, among other reasons, to avoid such skewing of the results by one major issue.

\section{Sample size}

As for the necessary length of the content analysis and sampling method, there is very little agreement across the existing literature, especially when it comes to newspapers.

When analyzing the content of newspapers, some scholars have used seven consecutive days [17], some have used 30 weekdays over a three-month spread [18] and others have used 150 days over a threeyear period [19].

As for the methodology, some scholars have used random sampling to select the specific days to be counted, while some have used systematic sampling and others have opted to simply analyze all issues throughout a smaller timeframe. One study analyzed the content of American newspapers, newsmagazines and websites to define the usual content readers receive [4]. The 16 newspapers used in that study were analyzed through a random sampling of 28 editions over a period from January 8 to October 6, 2003. Their selection was made based not only on circulation size, but also on geographical distribution, so as to 
better represent readers throughout the country. The study, however, did not analyze any newspapers outside the United States, as means of comparison, as the current study will.

Comparing the results in 2003 to the results of similar studies in the late 70s, the authors highlight how there was a clear decline in the coverage of government and domestic affairs on the covers, as well as of foreign affairs. Harder news was exchanged for softer news areas, including entertainment, personal health and science.

This study, nonetheless, will follow more closely the methodology applied by The Readership Institute [5], which analyzed the content of 52 newspapers with circulations ranging from 10,000 to one million daily copies. Its methodology consisted of a total of eight randomly selected issues within a 17-day timeframe. A random sample was used, as explained, to avoid a major event from skewing the results of the analysis, leading to findings that relate directly to the goals of this study.

Similar to the Readership Institute's study, this study performed two rounds of a continuous sample of 28 days (four full weeks) of daily newspapers, gathering data from all ten newspapers selected five in Brazil and five in the United States. Among those 28 days in each sampling period, a random sample of seven issues was selected, representing each day of the week. In this way, this study relied on random samples of each day of the week, avoiding, thus, a continuous coverage of a major issue that could skew the results of this study.

\section{Selection of newspapers}

Five newspapers have been selected in each of the sample countries. The newspapers in question have been selected based on the following non-exclusive factors:

Circulation size: The first step in selecting a newspaper was to build a list of the top 15 best-selling newspapers in Brazil and the United States, compiled for both countries based on existing data $[20,21]$.

Geographical distribution: Among the 15 newspapers on the top selling list for both countries, an attempt was made to select geographically diverse papers while representing the demographic distribution of the countries. In Brazil, for example, newspapers tend to be concentrated in a specific area of the country due to the highly skewed distribution of population towards the Southeast and Southern regions of the country; for this reason, newspapers from neighboring states such as Rio de Janeiro and São Paulo - by far the most populous in the country - were selected.

Availability (of newspapers and newspapers' front page): Another deciding factor on the selection of the newspapers to be analyzed was the availability of such newspapers. Newspapers had to either be available on paper at the Richter Library of the University of Miami, or an image of their daily front page available on the newspapers' web site (more essential, in this case, for samples from Brazilian newspapers, since this study was conducted while the author resided in the United States).

Normality: Specialized newspapers - those dedicated mostly to a specific niche - were excluded from the list of possible sample, as those would inherently skew their division of coverage of different kinds of news, leaving newspapers dedicated to general news. This exclusion left out, for example, the Wall Street Journal, in the U.S., which focuses mostly on financial news, and the Extra and Lance, in Brazil, which focus almost solely on sports news. Such exclusion is not uncommon within the literature, to avoid skewing of results due to content of news [4].

Most of these categories are commonly used ones [18] while others have been adapted to fit the specific needs of this study, as it includes comparison between countries and also graphic design details, for example.

The final selection of newspapers to be used as case studies, furthermore, was defined after a pilot test conducted during the week of January 7, 2010 to January 13, 2010. During that week, from Saturday to Friday, all ten initially proposed case study newspapers were collected and examined, to define not only whether the variables but also the publications themselves indeed fit this study and its goals.

Based on such categories and testing, specific newspapers were used as target samples for this study in each country. Ultimately, the five newspapers analyzed in the U.S. were: Chicago Tribune, Houston Chronicle, Los Angeles Times, New York Times and Washington Post. In Brazil, they were: Correio Braziliense, Correio do Povo, Gazeta do Povo, O Estado de São Paulo and O Globo.

All these newspapers have comparable resources in terms of international news services, subscribing to services such as the Associated Press, Agence France-Presse and, in the case of Brazilian publications, Brazilian news services such as the Agencia Estado. These services, along with news stories, many times also provide graphics and photos that are used alongside news stories published. Since most publications use news services to acquire their photos for international news stories, financial capabilities were not considered an issue for this study when examining the design of news stories.

The Los Angeles Times, The New York Times and Washington Post were also used as samples in previous studies [4], while the The New York Times and Los Angeles Times were the focus of research of Danielson and Lasorsa's analysis of 100 years of newspaper coverage [8].

\begin{tabular}{|l|l|l|}
\hline TOP-LEFT & TOP-CENTER & TOP-RIGHT \\
\hline MIDDLE-LEFT & MIDDLE-CENTER & MIDDLE-RIGHT \\
\hline BOTTOM-LEFT & BOTTOM-CENTER & BOTTOM-RIGHT \\
\hline
\end{tabular}

Table 1: Division of page into quadrants according to a newspaper's front page.

\begin{tabular}{|l|c|c|}
\hline Quadrant & Brazil & USA \\
\hline Top Left & 9.3 & 11.7 \\
\hline Top Center & 2.2 & 5.3 \\
\hline Top Right & 3.3 & 12.3 \\
\hline Middle Left & 22.5 & 8.8 \\
\hline Middle Center & 7.1 & 15.8 \\
\hline Middle Right & 12.1 & 13.5 \\
\hline Bottom Left & 15.9 & 9.9 \\
\hline Bottom Center & 11.0 & 12.9 \\
\hline Bottom Right & 16.5 & 9.9 \\
\hline
\end{tabular}

Table 2: Positioning of international stories on quadrant of front page, per country, in percentage of international stories. 


\section{Findings}

\section{Positioning of international story on page}

One of the most important elements to understanding the given importance of a specific story on the front page of a newspaper through design refers to where on the actual page the story is positioned. Among the on-going debates in news design is that of where readers' eyes fall first on a newspaper page. With that in mind, and in order to properly analyze the positioning of international stories on front pages of both Brazilian and American newspapers analyzed, this study divided the front page into nine different quadrants, as shown in Table 1. Stories were classified based on their starting point as to which quadrants they belonged to, resulting in the following values, represented in percentage.

As Table 2 shows, there is a difference between the positioning of international stories in Brazilian and American newspapers. In Brazil, the majority of international stories were positioned on the middleleft quadrant of the page, while, in American newspapers, the majority of stories were located on the middle-center quadrant of the page - a space considered more privileged, showing a tendency of American newspapers to highlight international stories more than Brazilian newspapers based on placement. A chi-square test confirmed the significant difference, with Chi Sq. $=34.005(\mathrm{~N}=353, \mathrm{df}=8)$ and $\mathrm{p}=.000$.

Since stories on the top third of the page are many times considered more prominent and important, an analysis compared the number of stories located on each third of the page (top, middle and bottom), of the page. As Table 3 shows, American newspapers divide the positioning of stories more evenly between the thirds of the page than Brazilian ones. American publications, also give international stories a better, more prominent placement than do Brazilian newspapers on their front pages. In American newspapers, 29.2 percent of international stories are located on the most prominent third (the top third) of the page; in Brazil, only 14.8 percent. Most stories in Brazil are located on the middle third of the page. A chi-square test confirmed the significance, with Chi Sq. $=11.486(\mathrm{~N}=353, \mathrm{df}=2)$ and $\mathrm{p}=.003$.

\section{Headlines and decks in international stories}

The analysis of headlines and decks (also referred to as sub headlines) included font size, number of lines, boldness and color. Since some of the stories did not include headlines (some teasers, mostly) and many others did not include decks, the analysis below refers to the characteristics of headlines and decks when those were

\begin{tabular}{|l|c|c|}
\hline Thirds & Brazil & USA \\
\hline Top & 14.8 & 29.2 \\
\hline Middle & 41.8 & 38.0 \\
\hline Bottom & 43.4 & 32.7 \\
\hline
\end{tabular}

Table 3: Location of story among third of page, per country, in percentage of international stories.

\begin{tabular}{|l|c|c|c|c|}
\hline & \multicolumn{2}{|c|}{ Headlines } & \multicolumn{2}{c|}{ Decks } \\
\hline Type of intro & Brazil & USA & Brazil & USA \\
\hline Stories with titles & 96.2 & 95.9 & 12.6 & 31.6 \\
\hline Stories without titles & 3.8 & 4.1 & 87.4 & 68.4 \\
\hline
\end{tabular}

Table 4: Use of headlines and decks in international stories, per country, in percentage of international stories. present. As shown in Table 4, out of the 182 international stories in Brazil, 96.2 percent presented a headline; in the U.S., 95.9 percent of the 171 international stories included a headline. As for decks, only 12.6 percent of stories in Brazil presented a headline, compared to 31.6 percent in the U.S. - showing a much higher tendency of American newspapers analyzed for this study to use decks in international stories than in Brazil. This difference in the usage of decks was confirmed significant, with Chi Sq. $=52.619(\mathrm{~N}=353, \mathrm{df}=1)$ and $\mathrm{p}=.000$.

\section{Adjusted font size of headline of international stories}

The study of the font size of the headline of international stories printed on the front page of the newspapers analyzed was done in two steps. At first, all headlines were measured in inches using the measuring tool available in Adobe Acrobat. The measurements were done from the baseline - the imaginary line on which the body of the letter sits - to the top of the initial uppercase letter. Once the headline was measured, this value was then compared to the actual overall size of the newspaper's front page, resulting in the adjusted font size. This became necessary when comparing font sizes across newspapers with different page sizes (tabloid versus broadsheet newspapers, for example). The result was a value that could be compared across newspapers in the same country, and across countries.

The actual adjusted size of headlines for international stories was almost equal between Brazilian (10.5) and American newspapers (10.0). This difference was confirmed as non-significant by a t-test, with $\mathrm{t}=.518(\mathrm{~N}=339, \mathrm{df}=339)$ and $\mathrm{p}=.605$.

\section{Color of headline in international stories}

Among the existing headlines, another variable used analyzed the color of the headline used the international story. From a graphic design perspective, since most headlines in a newspaper front page are black, headlines that are set in other colors would automatically differentiate such a story from others, thus increasing its salience and highlighting the topic in question.

As the sampling showed, black was indeed the color primarily used for headlines in both countries with respect to international stories. In the United States, all stories used black in their headlines; in Brazil, out of the 159 international stories with headlines, 96.2 percent used black headlines.

\section{Boldness of headline in international stories}

Another interesting variable of analysis related to the design of headline of stories refers to whether the headline is bolded or not. Design notions dictate that bolded headlines are likely to call more attention to stories than non-bolded ones; thus, stories with a bolded headline could be seen as having more salience than those without. Once more, there was not much difference in the design of international news between front page in Brazilian and American newspapers. While in Brazil 78.6 percent of the international stories analyzed had a bolded headline, in the U.S. that percentage was slightly smaller (69.4 percent), a different proven non-significant, with Chi Sq. $=2.958(\mathrm{~N}=339, \mathrm{df}=1)$ and $\mathrm{p}=.050$.

\section{Number of lines in headline of international story}

Aside from the color and boldness of headlines, another design aspect analyzed by this study was that of the number of lines used in the headline. In a simplistic analysis, the more lines here are in a story, the more salience one can apply to the story. 
As shown in and Table 5, there was a difference with respect to the number of lines used in headlines by Brazilian and American newspapers for international news stories. While in Brazil international stories had an average of 2.4 lines per headline, in the U.S., the average was 1.9 lines per headline - a significant difference, as shown by a $\mathrm{t}$-test with $\mathrm{t}=3.994(\mathrm{~N}=353, \mathrm{df}=350)$ and $\mathrm{p}=.000$. Also, in Brazil, most international stories had three lines in their headline (38.5 percent), while, in the U.S., most international stories ( 40.9 percent) had one line in their headline - a significant difference once more, as shown by a chi-square (Chi Sq. $=27.988, \mathrm{~N}=353, \mathrm{df}=5$ and $\mathrm{p}=.000$ ).

\section{Number of lines in decks of international stories}

Stories with decks or with longer decks are intuitively considered by readers to be more important than those without decks, and, thus, receive more salience. American newspapers also seem to present predominance over Brazilian newspapers, as seen in Table 6. Among the international stories with a deck, American newspapers seemed to use double the number of lines per deck than their Brazilian counterparts in this study, a significant difference, with $\mathrm{t}=7.980(\mathrm{~N}=105, \mathrm{df}=92)$ and $\mathrm{p}=.000$. Thus, not only did American newspapers use decks more often but also, when they did, their decks were twice the length of those in Brazilian newspapers.

\section{Use of art with international stories}

Another category of the analysis of the design of international news items on the front pages of newspapers in Brazil and the U.S. was the use of art along with the story. Art is considered one of the most powerful elements in a design to attract readers' attention (and, thus, give salience to a specific story).

While this study devised five different categories for art (aside

\begin{tabular}{|l|c|c|}
\hline Number of lines & Brazil & USA \\
\hline $\mathbf{0}$ & 3.8 & 4.1 \\
\hline $\mathbf{1}$ & 22.0 & 40.9 \\
\hline $\mathbf{2}$ & 20.9 & 26.3 \\
\hline $\mathbf{3}$ & 38.5 & 16.4 \\
\hline $\mathbf{4}$ & 14.3 & 12.3 \\
\hline $\mathbf{5}$ & 0.5 & 0.0 \\
\hline Total number of lines in headlines & 435 & 328 \\
\hline Mean number of lines in headline & 2.4 & 1.9 \\
\hline
\end{tabular}

Table 5: Number of lines of text in headline, in percentage of international news stories.

\begin{tabular}{|l|c|c|c|}
\hline Country & $\begin{array}{c}\text { Percentage of } \\
\text { stories with decks }\end{array}$ & $\begin{array}{c}\text { Mean number of } \\
\text { line in deck overall }\end{array}$ & $\begin{array}{c}\text { Mean number of } \\
\text { line in deck, when } \\
\text { present }\end{array}$ \\
\hline Brazil & 12.6 & 0.2 & 1.6 \\
\hline USA & 31.6 & 1.6 & 3.2 \\
\hline
\end{tabular}

Table 6: Number of lines in deck of international stories, per country.

\begin{tabular}{|l|l|l|l|}
\hline Country & $\begin{array}{l}\text { Number of int'l } \\
\text { stories with art }\end{array}$ & $\begin{array}{l}\text { Mean size of art within } \\
\text { Int'l story }\end{array}$ & $\begin{array}{l}\text { Mean size of art } \\
\text { within full front } \\
\text { page }\end{array}$ \\
\hline Brazil & $25.3 \%$ & $56.9 \%$ & $9.8 \%$ \\
\hline USA & $34.5 \%$ & $58.8 \%$ & $9.1 \%$ \\
\hline
\end{tabular}

Table 7: Number of international news stories containing art and mean size of art within full size of story, in percentage, per country. from the category of "no art"), in the end, three of them turned out to be useless. No newspaper made use of black and white photos, cartoons (including political cartoons) or even maps. The use of art in international stories in Brazil and the U.S. during the period and publications sampled was limited to color photos, infographics, mug shots or simply no art at all.

As the results show, the use of art along with international news seemed more common in American newspapers than Brazilian ones. A total of 74.2 percent of international news stories in Brazil had no art whatsoever accompanying them, while 63.7 percent of international stories in the U.S. did not have any art either.

\section{Size of art compared to story}

Another method of analyzing the use of art was to study the actual size of the art used with the story. In this case, the art element was measured in square inches using Adobe Acrobat's measuring tool. Then, the calculated area was compared to the overall area taken up by the story itself, to determine what percentage of the full area of the story was occupied by the art itself (thus, how important within the story the art was).

As shown in Table 7, out of all international stories in Brazil, 25.3 percent of stories carried some art with them, compared to in the United, 34.5 percent in the U.S. - a significant difference, as shown above. Moreover, the actual space occupied by the art within the full story, when the story did contain art, is similar between the two countries: in Brazil, whenever an international story had an art piece illustrating it, this art piece (or piece (or pieces) occupied a mean of 56.9 percent of all the space of the international story on the front page; in the U.S., the mean was 58.8 percent of the total size of the story on the front page - a non-significant difference, as show by $\mathrm{t}$-test with $\mathrm{t}=$ $.169(\mathrm{~N}=108, \mathrm{df}=106)$ and $\mathrm{p}=.866$.

Furthermore, there also seemed to be no statistically significant difference between the mean space taken by art accompanying international stories within the full front page of the newspaper, with art in international stories occupying an average of 9.8 percent of the full cover when present, compared to 9.1 in the U.S. For this comparison, $\mathrm{t}=.383(\mathrm{~N}=108, \mathrm{df}=106)$ and $\mathrm{p}=.703$.

\section{Conclusions}

As the results of this study showed, when it comes to design factors in newspapers, American publications seemed to give a higher salience to international stories compared to Brazilian publications, with most international stories being published in the middle-center quadrant of the page (and a large number of those in the top-right quadrant), a more prominent space than that occupied by the majority of international news items in Brazilian newspapers (middle-left). American newspapers also used decks (sub-headlines) more often than Brazilian newspapers, and had double the mean number of lines per deck per international story when a deck was present.

When it comes to using headlines as attention-getters for their international stories, however, Brazilian newspapers seemed to highlight international stories much more than American newspapers, by using larger headlines. From a news design standpoint, larger headlines are usually used in more important stories; headlines that take more space on the front page call more attention from readers than the ones that take less space. Such attention, of course, also relies on other elements, such as overall size of the article, the use of art, colors, 
and other design elements - also analyzed by this study. Headlines in Brazilian newspapers had a larger number of lines per headline and had a slightly larger font size than those in American newspapers. Headlines in international stories in Brazilian newspapers were also bolded more often than in American newspapers.

American newspapers used images in their international stories on the front pages more often than Brazilian newspapers did. And, while there was no statistically significant difference between the relative size of art pieces used in international stories in Brazilian and American newspapers, more international stories in the U.S. had accompanying art pieces than in Brazil.

Both countries, nonetheless, agreed on the type of art used with their international stories in newspapers. Almost all accompanying art in both Brazilian and American papers consisted of color photos; black and white photos, cartoons (including political charges) and infographics were barely used, or not used at all depending on the country. These results raise an interesting point, especially when it comes to American newspapers: even though the major focus of international stories in American newspapers was the war and Iraq, at no point did such stories have an accompanying map, at least not on the front page. While one would believe it to be only logical to use maps and infographics to show the geographical location or detailed graphical analysis of events (using the notion that a picture, or graphic, is worth a thousand words) that take place in more remote, more unfamiliar regions, apparently this is not important enough to secure space on the front page - only realistic, color photographs have their turn.

\section{Scope and Limitations}

This work is not done without its specific limitations, many of them defined by the character of the study itself - a dissertation done as a requirement for completion of a Ph.D. degree in international relations.

One such limitation, for example, comes down to the number of days used to collect data for this study, which totaled 15 in the end. While such number is an accepted number, as defined by an analysis of the existing literature on content analysis of daily periodicals' front pages (see Chapter Three, "Research Questions, Initial Hypothesis and Methodology"), a longer timeframe might allow for a more complete and deeper analysis of such periodicals.

As for the number and choice of specific periodicals, once more the resources of this study limited them. While the choice of periodicals followed a scientific and logical rationale (once more, see Chapter Three of this study for more details), it had to also count on the availability of the front page of such newspapers - in print or online, so that those could be analyzed. Especially in the case of Brazil, such limitations did interfere up to a point in the choice of periodicals to be used.

Furthermore, another problem with selection of specific mainstream papers arises, this time specifically in the United States: four media groups alone control nine out of the 15 best-selling newspapers in the country. In order to acquire an even broader and more accurate view of the American media in general, it would be interesting to examine not only the content of mainstream papers, but that of smaller papers too. This way, one could clearly state whether there is a discrepancy between smaller papers and bigger ones, and give a better perspective of the coverage of international news in American newspapers.

\section{Suggestion for Future Research}

An interesting, similar comparison could be made of the design of international news stories within news websites in different countries. Since the design of news stories in print and online are vastly different and extremely hard to be compared - due to both the way stories are designed and also the way people read stories online and in print - such comparison could not be performed for this study. However, a study that focused solely on comparing news websites would be an important follow-up to this study.

\section{References}

1. Adam PS, Garcia M (1990) Eyes on the news. Poynter Institute

2. Paskin D (2010) Coverage of International News in Brazilian and American Print Media. Global Media Journal, 5.

3. Graber DA (2002) Mass media \& American politics. (6th Edn), CQ Press.

4. The Project for Excellence in Journalism (2010) The state of the news media 2009 - overview: Content analysis.

5. The Readership Institute (2010) An analysis of content in 52 U.S. daily newspapers.

6. Freedom House (2001) Freedom in the world 2000-2001. Freedom House New York.

7. Freedom House (2002) Freedom in the world 2001-2002. Freedom House, New York.

8. Danielson WA, Lasorsa D (1997) Perception of social change: 100 years of front page content in the New York Times and the Los Angeles Times. In Roberts, C. W. (Editor), Text analysis for the social sciences: Methods for drawing inferences from texts and transcripts. Lawrence Erlbaum 103-115.

9. Rice S (2002) A Content Analysis of Select Black Newspapers: Representation of Black Conservatives from January - August 2001 (Master's Edn).University of Miami.

10. McCombs ME, Shaw DL (1972) The agenda-setting function of mass media Public Opinion Quarterly 36: 176-187.

11. Kim K, Barnett, GA (1996) The determinants of international news flow: A network analysis. Communication Research 23: 323-352.

12. Hicks RG, Gordon A (1974) Foreign news content in Israel and U.S newspapers. Journalism Quarterly 51: 639-644.

13. Robinson J, Sparkes VM (1976) International news in the Canadian and American press: A comparative news flow study. International Communication Gazette 22: 203-218.

14. Smith DA, White DR (1992) Structure and dynamic of the global economy: Network analysis of international trade 1965-1980. Social Forces 70: 857-893.

15. Hester A (1974) The news flow from Latin America via a world news agency International Communication Gazette 20: 82-98.

16. Schramm W (1981) International news wires and third world news in Asia In Richstad J, Anderson $\mathrm{MH}$ (Eds.), Crisis in international news. Columbia University Press, New York.

17. Peterson S (1981) International news selection by the elite press: A case study The Public Opinion Quarterly 45: 143-163.

18. Markham JW (1961) Foreign news in the United States and South American press. The Public Opinion Quarterly 25: 249-262.

19. Sigler JH (1969) News flow in the North African international subsystem. International Studies Quarterly 13: 381-397.

20. Instituto Verificador de Circulação (2009) Indice de circulação média de jornais brasileiro.

21. Editor \& Publisher Co (2009) Editor \& Publisher International Yearbook 2009 Editor \& Publisher Co. 